\title{
Nitrates, Water and Salt: Maintaining the Fertility of Agriculture
}

\author{
By D.S.G. Pollock, University of London
}

\begin{abstract}
In this essay, we examine the circumstances that are conducive to the maintenance of the fertility of agriculture in the various environments in which it is practiced. The fertility of the soil is dependent on an ample supply of nitrogen compounds and on a variety of other nutrients and trace elements. The supply of nitrates by natural means has posed a limit to productivity since the inception of agriculture; and the avoidance of soil salination has been a necessity in many environments.

Since the invention of an industrial process for fixing atmospheric nitrogen (the Haber Process), there has been an ample supply of nitrates in the form of chemical fertilizers, capable of sustaining agriculture worldwide and able to feed the burgeoning human population. The growth in supply has been attributable, in the second half of the 20th century, to the combined agency of hybrid crop species, chemical fertilisers and irrigation. Now, at the beginning of the 21st century, it is already apparent that the problem of soil salination is staunching the growth of the agricultural supply and threatening to reverse it.
\end{abstract}

\section{The Nitrogen Cycle}

We are often surprised by the sparse and seemingly inhospitable environments in which plants will grow. They will sometimes thrive in the absence of soil in a glass jar containing nothing but tap water. Indeed, the process of growing plants in water without soil and with a few added nutrients has been proposed as the ultimate recourse for deriving our foodstuffs in an imagined world lacking sufficient free land in which to practice the traditional methods of agriculture. This method of cultivating plants has been called hydroponics.

The reality of the survival of plants in seemingly sterile environments appears to contradict the nostrums of the proponents of organic farming who believe that, in order to thrive and to become fit for human consumption, plants must be cultivated in environments rich in the mulch of organic decay.

The truth is that plants are created largely from air and water. The process of photosynthesis, which occurs in all green plants, combines carbon dioxide, which is present in the air in small quantities, and water, which is essential to all forms of life, to create carbohydrates. The structural elements of plants are formed from carbohydrates

Photosynthesis also generates free molecules of oxygen. It is the activity of chlorophyll powered the energy of sunlight; and it is represented by the following chemical formula which shows that the creation of carbohydrates is accompanied by the release of free molecules of oxygen:

$$
6 \mathrm{CO}_{2}+6 \mathrm{H}_{2} \mathrm{O} \stackrel{\text { chlorophyll }}{\longrightarrow} \mathrm{C}_{6} \mathrm{H}_{12} \mathrm{O}_{6}+6 \mathrm{O}_{2}
$$


Chlorophyll, as its Greek name implies (kloros: green, phillon: leaf), is the green substance that colours our natural environment. The process of photosynthesis has converted the earth's atmosphere from its primordial state, in which it must have consisted preponderantly of carbon dioxide $\mathrm{CO}_{2}$ and methane $\mathrm{CH}_{4}$, to its present state, where it consists of a mixture of nitrogen ( $78 \%$ by volume) and oxygen ( $21 \%$ by volume), with only a trace of carbon dioxide - which has a concentration in air that has been rising steadily over the past 250 years and which, at present, is 380 parts per million by volume ( $0.038 \%$ by volume).

In fact, carbon dioxide and water are by no means all that is needed for the growth of plants. They require small but crucial quantities of minerals such as potassium, phosphorus, calcium, sulphur, magnesium and iron. More crucially, they require compounds of nitrogen in order to form the amino acids and proteins that are involved in all biological processes. Nitrogen is one of the constituent elements in chlorophyll and it is contained in the four nitrogen rich compounds that are the building blocks of the nucleic acid DNA. These are Adenine $\left(\mathrm{C}_{5} \mathrm{H}_{5} \mathrm{~N}_{5}\right)$, Cytosine $\left(\mathrm{C}_{4} \mathrm{H}_{5} \mathrm{~N}_{3} \mathrm{O}\right)$, Guanine $\left(\mathrm{C}_{5} \mathrm{H}_{5} \mathrm{~N}_{5} \mathrm{O}\right)$ and Thymine $\left(\mathrm{C}_{5} \mathrm{H}_{6} \mathrm{~N}_{2} \mathrm{O}_{2}\right)$.

Plants cannot obtain their nitrogen directly from the atmosphere. They must absorb it from the ground in the form of nitrogen compounds. Some of the nitrogen in the soil is subducted from the atmosphere, when nitric oxide and ammonia are formed by lightning and ultraviolet rays and are washed down in the rain. This source accounts for about $10 \%$ of the nitrogen compounds in the soil. The remainder is fixed in the soil as ammonia, nitrites, and nitrates by micro-organisms that take nitrogen directly from the air.

There are two kinds of nitrogen-fixing micro-organisms. There are freeliving bacteria, including the cyanobacteria (or blue-green algae) and symbiotic bacteria, which are commonly associated with leguminous plants, and with cereal grasses. The symbiotic nitrogen-fixing bacteria invade the root hairs of host plants, where they multiply and stimulate the formation of nodules, which contain plant cells and bacteria in intimate association. Within the nodules, the bacteria convert free nitrogen to nitrates, which the host plant utilises for its development. In return, it supplies the carbohydrates that nourish the bacteria. When leguminous plants die and decay, a substantial part of the nitrogen becomes available for uptake from the soil by other plants.

The nitrogen cycle consists of an endless process of growth and decay. Nitrogen may enter the soil as a molecule of nitric oxide or of ammonia, formed by lightning in a thunderstorm. Then, it may be absorbed by a bacterium or a plant, where it is converted to protein. Alternatively, it may be subducted directly from the air by a micro-organism. The protein will decay when the plant or the bacterium dies, thereby re-entering the pool of soil-bound nitrogen. Alternatively, the plant may be eaten by an animal and returned to the soil in its excreta or in its corpse when it decomposes on death. When it re-enters the 
soil, the nitrogen may be reused by plants and bacteria, or it may be converted back into nitrogen gas by certain micro-organisms (those which use nitrate as a source of oxygen), and thus returned to the atmosphere.

Today, the nitrogen cycle is greatly influenced by humans. Large quantities of the oxides of nitrogen are put into the atmosphere by the various processes of combustion that accompany human activity. Large quantities of manufactured nitrates are being put into the soil directly as agricultural fertilisers.

In many instances, these soils are largely sterile, with virtually no biological process occurring within them other than the growth of the crops in question. Moreover, modern farming methods may have the tendency, ultimately, of rendering the soil inhospitable to plants. To see these methods in their proper pserspective, it is helpful to consider briefly the history of agriculture since its inception.

\section{The Development of Agriculture}

It is widely believed that agriculture began some 10,000 years ago, at the end of the last ice age. It is nowadays supposed that there were at least three independent beginnings, which were in the Middle East, in China and in Meso America.

The best known of these origins was in the Middle East in the Fertile Crescent that comprises Egypt, the Levant (modern Palestine, Syrian and the Lebanon) and Mesopotamia (modern Iraq). This area is bounded in the north by the hills of Anatolia and Media (Persia) and in the south by the Syrian (Arabia) desert. It is watered by the Nile, the Jordan, the Euphrates and the Tigris.

Although the rivers may have been crucial in the rise of agriculture and civilisation in the Fertile Crescent, they were not the only factor. The area possessed the wild progenitors of the eight crops that were important in early agriculture. These were emmer, einkorn, barley, flax, chick pea, pea, lentil and bitter vetch. Also, the species that gave rise to four domesticated animals, which are cows, goats, sheep, and pigs, inhabited the area, and horses were close at hand.

It was once imagined that agriculture was an invention that mankind willingly adopted when in first became available. Modern opinion believes, to the contrary, that the people would not have forsaken the hunter-gathering lifestyle unless they had been forced to do so. By comparison with those of hunter gatherers, the lifestyles of early agriculturalists were exceedingly laborious.

Archaeological evidence shows that early farmers were greatly prone to disease and malnutrition. The evidence is in their stunted growth and in various afflictions of their bones. The inference is that they were forced to become farmers by circumstances beyond their control. These entailed the loss of forest cover and the desiccation of the environments which, previously, would have sustained hunting and nomadic pastoralism. 


\section{D.S.G. POLLOCK: NITRATES, WATER AND SALT}

Early agriculturalists would have had little regard to the preservation of the fertility of the soil. The available land may have been sufficient to allow migration from wasted soils to fresh ones. Eventually, as population densities increased, a system would have arisen of systematically revisiting land that had been left fallow in order to regain its fertility. The frequency with which the land was revisited would have increased with the density of the population.

By Roman times, a two-course rotation of crops was common throughout the Mediterranean and much of Europe. In one year, wheat, barley or rye were sown in the autumn and harvested in the late summer. In the following year, the land was left fallow, which is to say that it was ploughed and harrowed, but left unsown.

Another recourse in the Fertile Crescent, in the face of declining soil fertility, was to resort to irrigation. The banks of rivers are apt to be clothed in verdant vegetation; and irrigation would have begun in fields adjacent to the rivers. The fertility of the fields would have been sustained partly by the ample supply of moisture and partly by the nutrients that are carried by the river waters in the form of dissolved minerals and the products of biological decay. Thus, in the Nile valley, a specialised agriculture developed in which the annual flooding by nutrient rich waters was relied upon to restore the fertility of the soil.

In Mesopotamia, systematic irrigation began in the the southern area between the Tigris and the Euphrates rivers, and it moved rapidly upstream. The archaeological evidence shows that early Mesopotamian (i.e. Sumerian) agriculture was beset by the inevitable curse of irrigated agriculture when it is pursued in places where the water is subject to a high rate of evaporation. This is the salination of the soils. It has been suggested that, over a period of 300 years of cultivation, the wheat yield dropped to a third of its original quantity. This loss of fertility led, eventually, to the collapse of the Sumerian civilisation.

The agriculture of the Middle East gradually pervaded the lands of the Mediterranean. It made its way into southern Europe and thence into Northern Europe where, in the early Middle Ages, it must have resembled Roman agriculture. However, as the population grew, it was no longer possible to have half of the cleared land in fallow.

From the time of Charlemagne in the 8th century onwards, a three-course crop rotation became increasingly common in Europe. One year of spring crops was interpolated between the year of winter cereals and the year of fallow. Less demanding species of cereal crops such as oats, or buckwheat were grown. Nitrogen-fixing leguminous crops, such as peas and beans were grown in the north of Europe and lentils and chickpeas were grown in the south. While the legumes left some residual nitrogen for the succeeding serial crops, they were not able to improve the fertility of the soil; and its the nutrient depletion was exacerbated. 
The fertility of the soil must have been severely affected by the time of the Black Death, which struck Europe in 1348. This pandemic relieved Europe of up to $30 \%$ of its population. The reduced demand for food would have allowed some of the soils to regain their fertility. However, a further 400 years were to elapse before any significant advances were made in European farming methods.

\section{The Agricultural Revolution}

A revolution occurred in agriculture in the 18th century in Europe. It was Britain that led the way. The impetus for the revolution was doubtless the increasing population, which required to be fed. In 1750, the English population stood at about 5.7 million. It reached 16.6 million in 1850, and agricultural output expanded with it.

The population was increasingly urbanised. Being divorced from the land, its demands widened the market for agricultural produce. The market was also stimulated, at the end of the 18th century and in the early years of the 19th century, by the wars with France, which necessitated the provisioning of large military forces and which inhibited the importation of foodstuffs.

The increase in the production of food was accompanied by a revolution in agricultural methods. School textbooks associate the changes with the names of persons who are supposed to have been amongst the leading innovators. Amongst those who are remembered are Jethro Tull, Lord Townshend, Arthur Young, Farewell, Coke of Hookahs and the Collins. Modern opinion tends to doubt their importance and to suggest that they were merely the protagonists of a process that was already well underway.

Turnip Townshend (1675-1738) was famous for advocating the planting of turnips in a four-field rotation of crops involving wheat, turnips, barley and clover, which was known as the Norfolk system. The system had been pioneered by the Dutch, and turnips were certainly becoming increasingly common in English fields at the time of Townshend's birth. He did not, as the textbooks tell us, introduce them from Hanover. Turnips and clover both have good nitrogen-fixing properties, and the new system of crop rotation enabled land that, previously, had been devoted permanently to pasture to be put to the plough.

The types of crops also changed, when low-yielding types, such as rye, were replaced by higher-yielding types such as wheat and barley. Although the balance between arable land and permanent pasture changed in favour of the former, this did not cause the supplies fodder to decrease. For the loss of pasture was made good by the turnips and the clover, which were the new fodder crops. Thus, not only did these crops result in an increase in fodder yields, but they were also instrumental in turning many lowland heaths from rough pasture into productive arable farms.

As the nitrogen supply was improved, other nutrients, particularly phos- 


\section{D.S.G. POLLOCK: NITRATES, WATER AND SALT}

phorus and potassium, became limiting factors. The growth of the nitrogenfixing clover and lucerne (or alfalfa) was hampered by the availability of phosphates.

\section{Chemical Fertilisers}

Up to the beginning of the 19th century, farmers had relied upon three methods to maintain the fertility of their arable lands by supplying the nutrients of plants. They relied upon animal waste in the form of farmyard manures and bone meal. They used the roughage and litter collected from meadows and forests. As part of a cycle of crop rotation, they used leguminous crops, which had the effect of fixing atmospheric nitrogen in the soil,

By the middle of the 19th century, much of the available farm land of Britain was already in intensive used; and further supplies of foodstuffs could only be obtained by increasing the yield of existing fields. This required the addition of nutrients that were exogenous to the farming system. From that time onwards, chemical fertilisers, in the form of nitrogen compounds, were added to the fields in increasing quantities.

In the early years, the nitrate fertilisers were imported minerals. The production of sodium nitrate began in 1804 in the Atacama desert that spans Chile, Peru and Bolivia. Its initial use was in gunpowder; and nitrates continue to this day to be used as explosives. This salt was leached out of the soil by hot water, and it was then purified and dried. This was an expensive process, Nevertheless, it continued in use for many years; and the supplies from this source reached their peak in the 1930's.

The dominant source of nitrates in much of the latter half of the 19th century was Peruvian guano. This is a mixture of phosphorus and ammonium nitrates that has it origin in the dropping of sea birds. It was gathered from small islands near the coast of Peru. Beginning in about 1840, guano was imported into Europe in increasing quantities until the deposits were virtually exhausted by 1875 . At that stage, the Chilean nitrates became the dominant supply.

A subsidiary source of nitrate fertiliser, which arose at the end of the 19th century and which has endured to the present day, is the ammonium sulphate $\left(\mathrm{NH}_{4}\right)_{2} \mathrm{SO}_{4}$ that is generated by the process of coking coal. This process was associated with the production of town gas, which was a main source of lighting up the end of the 19th century and of domestic heat until more recently, when it was replaced in Britain by natural gas. The coking process is also associated with the making of steel.

Given the increasing demand for nitrates, and in view of the rapid depletion of the sources of mineral nitrates, it was inevitable that, at the end of the 19th century, industrial chemists should turn their attention to the business of creating synthetic nitrates. In a widely published lecture of 1898, the English chemist Sir William Crookes called upon chemists of all nationalities to find 
Table 1: World nitrogen production according to process (1000 t N) (other byproduct nitrogen originally derived from the Haber-Bosch synthesis, is included under "synthetic ammonia"), from Smil (2001).

\begin{tabular}{|c|c|c|c|c|c|r|r|}
\hline $\begin{array}{c}\text { Fertiliser } \\
\text { year }\end{array}$ & $\begin{array}{c}\text { Chilean } \\
\text { nitrate }\end{array}$ & Guano & $\begin{array}{c}\text { Coke-oven } \\
\text { ammonium } \\
\text { sulphate }\end{array}$ & $\begin{array}{c}\text { Calcium } \\
\text { cyanamide }\end{array}$ & $\begin{array}{c}\text { Electric } \\
\text { arc Ca. } \\
\text { nitrate }\end{array}$ & $\begin{array}{c}\text { Synthetic } \\
\text { ammonia }\end{array}$ & Total \\
\hline 1850 & 5 & - & 0 & 0 & 0 & 0 & 5 \\
1860 & 10 & 70 & 0 & 0 & 0 & 0 & 80 \\
1870 & 30 & 70 & 0 & 0 & 0 & 0 & 100 \\
1880 & 50 & 30 & 0 & 0 & 0 & 0 & 80 \\
1890 & 130 & 20 & - & 0 & 0 & 0 & 150 \\
1900 & 220 & 20 & 120 & 0 & 0 & 0 & 360 \\
1910 & 360 & 10 & 230 & 10 & - & - & 610 \\
1920 & 410 & 10 & 290 & 70 & 20 & 150 & 950 \\
1930 & 510 & 10 & 425 & 255 & 20 & 930 & 2150 \\
1940 & 200 & 10 & 450 & 290 & - & 2150 & 3100 \\
1950 & 270 & - & 500 & 310 & - & 3700 & 4780 \\
1960 & 200 & - & 950 & 300 & - & 9540 & 10990 \\
1970 & 120 & - & 950 & 300 & - & 30230 & 31600 \\
1980 & 90 & - & 970 & 250 & - & 59290 & 60600 \\
1990 & 120 & - & 550 & 110 & - & 76320 & 77100 \\
2000 & 120 & - & 370 & 80 & - & 85130 & 85700 \\
\hline
\end{tabular}

a way to fix nitrogen from the unlimited quantities in the air. He proposed that, without some new source of nitrogen fertiliser, there would be widespread famine within two or three decades. Some intensive research ensued.

Already, in 1895, Adolf Frank and Nikodemus Caro had found that, at $1,000^{\circ} \mathrm{C}$, calcium carbide combines with nitrogen from the air to form calcium cyanamide. When calcium chloride was added, the temperature could be lowered to $300^{\circ} \mathrm{C}$. The first commercial plant for creating calcium cyanamide was built in 1905 in Italy, followed by two plants in Germany in 1907 and 1908. The production of calcium cyanamide depended upon ample supplies of cheap energy. Two of the plants were powered by hydroelectricity and the third by local lignite.

Another process for fixing nitrogen was devised in imitation of the natural processes whereby Nitric oxide NO is created in the atmosphere by lightening. In 1903, the Norwegians Kristian Birkeland and Samuel Eyde used powerful electromagnets to deform an electric arc into a disc-shaped flame within a stream of air. After passing through the $3,500^{\circ} \mathrm{C}$ flame, the air contained $1.5-$ $2.0 \% \mathrm{NO}$, which was precipitated in water to give nitric acid, which was then neutralised with calcium carbonate. Although very demanding of energy, the process was economic when based on hydroelectricity. In 1913, three plants were operating in Norway and producing a quantity of nitrates equivalent to 


\section{D.S.G. POLLOCK: NITRATES, WATER AND SALT}

about $3 \%$ of the nitrogen exported in Chilean nitrate in the same year.

The limitation of both these processes was the demand on energy; and other means producing the nitrates were sought. In 1904, Fritz Haber, professor of chemistry at the University of Karlsruhe in Germany, succeeded in synthesising ammonia $\mathrm{NH}_{3}$ from its constituent elements, which are hydrogen and nitrogen. The yield of his process was so low that he gave up. However, he tackled the problem anew in 1908 and discovered a method that he succeeded in patenting. Using an osmium catalyst at 175-200 atmospheres pressure and $550-600^{\circ} \mathrm{C}$, about $6 \%$ of the gas mixture was transformed into ammonia. The chemical formula for the reaction is very simple:

$$
\mathrm{N}_{2}+3 \mathrm{H} 2 \longrightarrow 2 \mathrm{NH}_{3}
$$

To realise the process on a industrial scale, Haber approached the chemical company 'Badische Anilin und Soda-Fabrik' (BASF) of Ludwigshafen, Germany. Fritz Haber and Carl Bosch, who was one of the company's employees, succeeded in overcoming the remaining problems that were besetting the process, some of which were affecting the reaction vessels and were of a metallurgical nature. Both of the inventors of the process were honoured with a Nobel prize, Haber in 1918 and Bosch in 1931.

In 1913, the first commercial plant with a substantial capacity came on stream in Oppau close to Ludwigshafen; and the capacity was rapidly increased. The Haber-Bosch process arrived in time to make a substantial contribution to Germany's munitions industry during the First World War. Later, as Table 1 indicates, it became the dominant process for creating nitrogen compounds, dwarfing all other processes. Today $99 \%$ of the industrially fixed nitrogen is produced using the Haber-Bosch process. The process has has been refined over the years and it has become world-wide. The nitrogen which is supplied to the process comes from the air. The hydrogen that is reacted with it nowadays comes from natural gas (methane).

\section{The World's Dependence on Nitrate Fertilisers}

According to the best authority on the subject, who is Vaclav Siml (1999), during the mid-1990s about $85 \%$ of all nitrogen in food proteins available for human consumption came directly in plant foods or indirectly from the world's croplands via animal products. The rest came from pastures and from aquatic foods. Because synthetic nitrogen fertilisers provided about half of the nutrient in harvested crops, roughly $40 \%$ of the world's dietary protein supply in the mid-1990s originated in the Haber-Bosch synthesis of ammonia.

According to Siml "Low-income countries now consume about two-thirds of the world's nitrogen fertilisers, which provides about $55 \%$ of the total nutrient supply reaching their fields. Because no less than $92 \%$ of their food proteins is derived from crops, inorganic fertilisers supply at least half of all nitrogen 
in their diets. This would be an equivalent of feeding no less than 2.2 billion people or roughly $40 \%$ of the world's 1996 total population: these people now depend on the Haber-Bosch synthesis for what is, on the average, a barely sufficient supply of their basic food needs, that is, for their very survival."

"Another estimate of our dependence on ammonia synthesis can be obtained by an entirely different approach - by calculating the population totals supportable by specified diets. In 1900, the virtually fertiliser-free agriculture was able to sustain 1.625 billion people by a combination of extensive cultivation and organic farming on the total of about 850 mio ha. The same combination of agronomic practices extended to today's 1.5 billion ha of cropland would feed about 2.9 billion people or about 3.2 billion when adding the food derived from grazing and fisheries. This means that, without nitrogen fertilisers, no more than $53 \%$ of today's population could be fed at the generally inadequate per capita level of 1900 diets. If we were to provide today's average per capita food supply with the 1900 level of agricultural productivity, we could feed only about 2.4 billion people or just $40 \%$ of today's total."

\section{The Green Revolution}

In the period immediately following the 2nd World War, there was anxiety at the prospect of a world-wide famine. It appeared that the world's agricultural production would not be sufficient to feed its burgeoning population. However, research was already underway to develop high-yielding crops that might replace traditional varieties in developing countries around the world.

Since then, a Green Revolution - so called - has ensued that has greatly increased crop yields in India, Pakistan, the Philippines, Mexico, Sri Lanka and in many other third-world countries. The food production of China has also surged ahead. The revolution began in 1945 when the Rockefeller Foundation and the Mexican Government established the Co-operative Wheat Research and Production Program with the aim of improving the agricultural output of that country's farms.

The chief scientist employed by the program was Norman Borlaug who, in 1970, won the Nobel peace prize for his efforts. The technology that was developed by the program was exported around the world; and the hybrid strains of cereal crops that were produced are often regarded the primary cause of the revolution.

However, the Green Revolution has had other mainstays. The first these factors has been the extensive use of chemical fertilisers. As has already been indicated, these have been primarily nitrogen fertilisers, which have depended for their manufacture on the Haber process.

It is notable that, whereas a wide range off nitrate fertilisers are used in European and North American agriculture, third-world agriculture is dominated by a single fertiliser, which is urea $\left(\mathrm{NH}_{2}\right)_{2} \mathrm{CO}$. This fertiliser, which conveys nothing but nitrogen to the plants, accounts for $70 \%$ of the the third-word 
consumption of fertilisers.

The second mainstay of the Green revolution has been irrigation, which, in India and Pakistan, has made it possible to have more than one harvest per year, and which as reduced the dependence of agriculture on the monsoon season. A third factor is the mechanisation of agriculture's which has greatly reduced its dependence on human labour.

A fourth vitally important factor has been the use of chemical pesticides and herbicides, including organochlorine and organophosphate compounds. These have enabled efficient weed control and have also been used in the eradication of insect pets. They have enabled the development of cereal monocultures, which might otherwise have been far more problematic. In this connection, one should recall that one of the virtues of a system of crop rotation is that it limits the spread of pests that are specific to particular crops.

There are anxieties concerning the sustainability of all four of these factors. The one which is set to pose the greatest and most imminent threat to the fertility of the soil and to the productivity of agriculture in the third world is the salination that is occasioned by irrigation, and which might described as its inevitable accompaniment.

\section{Salination, Waterlogging and the Loss of Croplands}

Salination is the accumulation of salts in the soil to an extent that they inhibit the growth of plants. The salts are the product of the breakdown of rocks and minerals through weathering. All water that passes through the soil is bound to dissolve these salts. The longer is its course through the soil, the greater is its burden of salts.

If the water leaves the soil through evaporation, then its salt content will be deposited, thereby increasing the salinity of the soil. If the water runs freely to a river and thence into the sea, then it may serve to flush salts out of the soil. In an environment characterised by a given topography, climate and soil types, an equilibrium may be reached in time where the salinity of the soil is constant.

However, the practice of irrigation in dry climates tends to increase the soil salinity by changing the balance of the water cycle. It increases the passage of salts through soil, and it allows them to accumulate therein through an enhanced rate of evorporation.

A secondary effect of irrigation is to raise the level of the water table. If the ground water is saline and if it reaches a level of 2.5 metres below the surface of the soil, then it is liable to be drawn upwards by the capillary action of the roots of plants. This will add to the burden of salts. Thus, the so-called problem of waterlogging is an adjunct of the problem of salinity. It can be overcome only by limiting the quantity of the irrigating waters and by ensuring that they are sufficiently drained from the soils.

There are many historical instances in which salination has destroyed the 


\section{D.S.G. POLLOCK: NITRATES, WATER AND SALT}

fertility of agriculture and has led to economic and societal collapse. The decline of the Sumerian civilisation, which occupied the lowland plains of Mesopotamia, is the earliest well-know instance, if only because that this is the earliest agriculture that has been studied in detail.

The Sumerians began their occupancy of the area some 6,000 years ago. The succeeding civilisations of the Babylonians and the Assyrians suffered the same fate of agricultural collapse, which must have been due in large measure to the destruction of the fertility of their soils in consequence their agricultural practices, which included extensive irrigation.

In her book The Pillar of Sand, which is subtitled Can the Irrigation Miracle Last? Sandra Postel asserts that "A key lesson from history is that most irrigation-based civilisations fail." She asks whether ours will be any different. The miracle to which she alludes is the Green Revolution, which has been brought about, jointly, by irrigation and chemical fertilisers.

The modern era of irrigation began in the mid 19th century. At that time, the British began to pursue large-scale irrigation projects in India and in what is now Pakistan, notably in the Indus valley. Already by 1871, even before the lower Ganges canal on the other side of the subcontinent was opened, an increasing incidence of soil salination was being reported. The colonial commissioner of the Agra Division was arguing that the evil of salination demanded an immediate remedy.

The hydrological engineering in the Indian subcontinent reached its peak in the 1930's, which was in time to sustain the Green Revolution which began 30 years later. The revolution has already faltered; and there are signs that it is going into reverse. This should be entirely predictable in view of the lessons or more than a century ago.

Notwithstanding these lessons, there have been many subsequent instances of misguided irrigation projects that have courted disaster by taking no steps to mitigate the effects of salination. The most notable of these has been the Soviet scheme to divert the rivers that fed the inland Aral sea and to use them, instead, to create a cropland to rival the American mid west.

The story of the consequent disappearance of the Aral sea and of the creation of a desert filled with sand, salt and the toxic wastes of pesticides and fertilisers is one that is often told-see, for example, Saiko (2001). Nevertheless, similar schemes of an even greater magnitude have been embarked upon in China, with an equal disregard of the consequences, which may be described as imminent as well as long-term. It seems that hydrological engineering has a fatal attraction for totalitarian regimes and for rulers who wish make their mark with monumental engineering works.

The consequences of the resulting loss of croplands have to be measured in view of the continuing growth of the global population, which requires to be fed. These losses will have to be measured in conjunction with an even greater loss of low-lying fertile land in consequence of a rising sea level. This will be 
due to the thermal expansion of ocean waters, which will be a result of the global warming that is already well underway.

\section{Glossary}

AMMONIUM NITRATE, $\mathrm{NH}_{4} \mathrm{NO}_{3}$. The most common use of ammonium nitrate is in fertilisers. This is due to its high Nitrogen content (a desirable feature of fertilisers) and easy (and therefore inexpensive) industrial manufacture. It is also used in explosives e.g., ammonal and ammatol.

CHLOROPHYLL. A green pigment contained in the leaves of green plants. It absorbs energy from sunlight to build up sugars and carbohydrates by the process of photosynthesis. Chlorophyll consists of two distinct substances chlorophyll- $a \mathrm{C}_{55} \mathrm{H}_{72} \mathrm{O}_{5} \mathrm{~N}_{4} \mathrm{Mg}$ and chlorophyll- $b \mathrm{C}_{55} \mathrm{H}_{70} \mathrm{O}_{6} \mathrm{~N}_{4} \mathrm{Mg}$.

FERTILISERS. Material put in the soil to provide compounds of elements essential to plant life, particularly, nitrogen, phosphorus and potassium.

GUANO. Large deposits formed from the excrement and bodies of sea birds. Found on Islands of the coast of Peru. Very rich in nitrogen and phosphorus compounds. Valuable as fertiliser.

GUNPOWDER. Mixture of Potassium Nitrate $\mathrm{KNO}_{2}$, powdered charcoal and sulphur. When ignited a number of chemical reactions take place producing gasses, thus causing an explosion in a confined space.

NITROGLYCERINE, (glyceryl tribitrate), $\mathrm{C}_{3} \mathrm{H}_{5}\left(\mathrm{NO}_{3}\right)_{3}$. Pale yellow, heavy oily liquid. Explodes with great violence when subjected to sudden shock of detonation. Used as an explosive, either alone or in the form of dynamite, which is nitro glycerine stabilised by absorption in hydrated silica.

NITROGEN CYCLE. The circulation of nitrogen compounds in nature through various organisms to which nitrogen is essential. Inorganic nitrogen compounds in the soil are taken in by plants and are combined by the plants with other elements to form proteins, the form in which nitrogen can be utilised by higher animals. The result of animal waste and decay is to bring the nitrogen, which the animals have absorbed in the form of proteins, back into the soil in the forms of simpler nitrogen compounds. Bacterial actions of various kinds convert these into compounds suitable for use by plants again. In addition to this main circulation, a certain amount of atmospheric nitrogen is fixed (i.e. combined) by the action of bacteria associated with the roots of leguminous plants and by the action of atmospheric electricity, while some combined nitrogen is set free by the action of denitrifying bacteria.

SALTPETRE, (potassium nitrate), $\mathrm{KNO}_{2}$.

UREA, (carbamide), $\left(\mathrm{NH}_{2}\right)_{2} \mathrm{CO}$. A white crystalline organic compound. It occurs in urine. It was the first organic compound to be synthesised from nonorganic materials when it was produced in 1773 by Hillaire Rouelle.The event is 


\section{D.S.G. POLLOCK: NITRATES, WATER AND SALT}

commonly regarded as the starting point of organic chemistry. Urea is a simple and cheap fertiliser that is wide used in the agriculture of third-world counties. Human urea was used in the manufacture of gunpowder in Elizabethan times and it was used, until very recently, in fixing textile dyes.

\section{Bibliography}

Chorley, G.P.H., (1981), The agricultural revolution in Northern Europe, 1750 1880: Nitrogen, legumes, and crop productivity, Economic History, 34, 71-93.

Crookes, W., (1899), The Wheat Problem, London.

Hall, S.J.G, and J. Clutton-Brock, (1989), Two Hundred Years of British Farm Livestock. British Museum [Natural History].

Mannion A.M., (1995), Agriculture and Environmental Change: Temporal and Spatial Dimensions, John Wiley and Sons, Chichester.

Overton, M., (1996), Agricultural Revolution in England: The Transformation of the Agrarian Economy 1500-1850, Cambridge University Press.

Postel, S., (1999), Pillar of Sand: Can the Irrigation Miracle Last? W.W. Norton and Co., New York

Saiko, T., (2001), Environmental Crises: Geographical Case Studies in PostSocialist Eurasia, Prentice-Hall, Harlow.

Smil, V., (2001), Enriching the Earth: Fritz Haber, Carl Bosch, and the Transformation of World Food Production, MIT Press .

Smith, B.D., (1995), The Emergence of Agriculture, Scientific American Library, W.M. Freeman and Co, New York.

Turner, M.E., J.V. Beckett and B. Afton, (2001), Farm Production in England 1700-1914, Oxford University Press.

Thirsk, J., (ed.), (1967-1989), The Agrarian History of England and Wales, vol. IV, 1967; vol. V, 1985; vol. VI, 1989, Cambridge University Press.

Williamson, T., (2002), The Transformation of Rural England: Farming and the Landscape, 1700-1870, Exeter University Press. 